\title{
Correction: Acceptability of the Fitbit in behavioural activation therapy for depression: a qualitative study
}

Chum J, Kim MS, Zielinski L et al. Acceptability of the Fitbit in behavioural activation therapy for depression: a qualitative study. Evid Based Mental Health 2017;20:128-33. 10.1136/ebmental-2017-102763.

A statement indicating that authors Jenny Chum and Min Suk Kim are co-first authors should have been included in this manuscript.

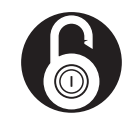

\section{OPEN ACCESS}

Open Access This is an Open Access article distributed in accordance with the Creative Commons Attribution Non Commercial (CC BY-NC 4.0) license, which permits others to distribute, remix, adapt, build upon this work non-commercially, and license their derivative works on different terms, provided the original work is properly cited and the use is non-commercial. See: http:// creativecommons.org/licenses/by-nc/4.0/

(c) Article author(s) (or their employer(s) unless otherwise stated in the text of the article) 2018. All rights reserved. No commercial use is permitted unless otherwise expressly granted.

Evid Based Mental Health 2018;21:76. doi:10.1136/ebmental-2017-102763corr1

D) Check for update 